\title{
The evolution of sheep production in Rio Grande do Sul and Uruguay: a comparative analysis of structural change
}

\author{
Evolução da produção ovina no Rio Grande do Sul e Uruguai: análise comparativa de \\ mudança estrutural
}

João Garibaldi Almeida Viana ${ }^{\mathrm{I}}$ Paulo Dabdab Waquil ${ }^{I I}$

\begin{abstract}
This study intended to analyze comparatively the evolution and the structural changes in sheep production in Rio Grande do Sul and Uruguay, being the international wool crisis used as a reference point. The analysis method was based on an econometrics time series, and the analysis began with the estimation of models that used linear and semi logarithmic regression. The estimation of the models proved that there were structural changes in sheep production in these regions, and this estimation used the wool crisis as a point of reference. In Rio Grande do Sul after 1990, the variables of sheep stock, wool and sheep meat presented a negative variable in their posted annual growth rates, as they decreased by $5.9 \%, 5.6 \%$ and $5.6 \%$, respectively. The negative growth rates in Uruguay for the same variables in the same period were $6.1 \%, 5.6 \%$ and $0.9 \%$, respectively. The data models indicate that there was no return to a balanced situation after the changes caused by the crisis. Therefore, the sheep market was permanently affected, which dynamically determined the evolution of sheep production and was defined by changes and uncertainty.
\end{abstract}

Key words: agribusiness, agricultural economics, sheep-raising.

\section{RESUMO}

$O$ artigo teve por objetivo analisar comparativamente a evolução e a mudança estrutural da produção ovina no Rio Grande do Sul e Uruguai utilizando como ponto de referência a crise internacional de lã. O método de análise baseou-se na econometria de séries temporais, partindo da estimação de modelos de regressão linear e semilogarítmica. A estimação dos modelos comprovou a mudança estrutural na produção ovina do Rio Grande do Sul e Uruguai, tendo como referência a crise da lã. No Rio Grande do Sul, as variáveis de rebanho ovino, produção de lã e de carne ovina apresentou uma variação negativa em sua taxa anual pós-1990 de 5,9\%, 5,6\% e 5,6\%, respectivamente. No Uruguai, as taxas negativas foram de 6,1\%,5,6\% e 0,9\%, para as mesmas variáveis do período. Os dados dos modelos indicam que não houve retorno a uma situação de equilíbrio após as transformações da crise. Assim, o mercado ovino foi afetado de forma permanente, determinando a evolução da ovinocultura nas regiões como uma trajetória dinâmica, definida por mudanças e incertezas.

Palavras-chave: agronegócio, economia agrícola, ovinocultura.

\section{INTRODUCTION}

Sheep production stands is a traditional economic activity in Rio Grande do Sul (a state in the South of Brazil) and Uruguay. During the $20^{\text {th }}$ century, sheep production in these regions was affected by alternating periods of progress and crisis that modified strategies and dynamics in the agribusinesses of the sheep industry.

Sheep production has been a commercial option in both regions since the beginning of the $20^{\text {th }}$ century, and this production primarily grew during the 1940s and 1950s, due to the value of wool, the creation of cooperatives and technological developments. The primary aspect of the more recent economically imbalanced situation began in the second half of 1980, when political and organizational measures were placed to protect the wool market from the largest world producer, namely, Australia. Because the Australians were aware of the necessity of protecting the sheep wool industry, they created a commercial system that is known as the Australian Wool Corporation-a

IUniversidade Federal do Pampa (UNIPAMPA), Campus Santana do Livramento, Rua Barão do Triunfo, 1048, 97573-590, Santana do

Livramento, RS, Brasil. E-mail: joaoviana@unipampa.edu.br. Autor para correspondência.

"Departamento de Economia, Universidade Federal do Rio Grande do Sul (UFRGS), Porto Alegre, RS Brasil. 
regulatory agency that has raised the prices of wool in the world market (BOFILL, 1996). Maximizing profits by increasing fiber prices was a consistent goal of the Australian Wool Corporation, and this practice challenged buyers to change their marketing habits.

Due to the worldwide crisis in wool sales that occurred during the 1980s and 1990s, many producers abandoned the sheep industry, which caused a loss in the structure of the productive chain. Consequently, many of the areas that had previously been reserved for sheep husbandry began to be used for cattle and grain production (DIEA/ MGAP, 2008), and furthermore, the remaining sheep production became a secondary livestock activity. This phenomenon changed in 2000, when the sheep sector began to restructure itself using sheep meat as the main product of its supply chain.

The available literature that attempts to explain the changes and the evolution in sheep production is restricted and includes technical discussions about the production systems and the identification of the main periods in the crisis. The international wool crisis caused changes that were barely studied. It also reflects a lack of economic data and research that analyze the modifications and imbalances of the sheep-producing sector.

Because of these limitations, this article is intended to compare the analyses of the evolution and structural changes in sheep production in Rio Grande do Sul and Uruguay, and it uses the international wool crisis as a point of reference. Thus, this research intend to elucidate the dynamics of the production chain as well as the sheep sector's behavior when producers face an imbalanced environment. From a practical perspective, the analyses of the structural evolution of sheep production should provide some useful data that may be reflected in both the public and private sector strategies that are intended to strengthen this industry.

\section{MATERIAL AND METHODS}

The quantitative method of research was based on time series. The methodological procedure began with historical series of data that were related to sheep meat, wool production and sheep stock. These data extend from 1974 to 2009-2010, and special consideration is given to the period before and after the wool crisis in the late 1980s and the beginning of the 1990s. In Uruguay, the data were gathered by Ministerio de Ganaderia Agricultura y Pesca (DIEA, 2011). In Rio Grande do Sul, the same data were collected by the Brazilian Institute of Geography and
Statistics (IBGE, 2011). Due to the lack of available data concerning sheep meat production in Rio Grande do Sul, an estimated data series was obtained by multiplying the meat production in Brazil (FAO, 2011) by the percentage of the sheep stock of Rio Grande do Sul in relation to national stock (IBGE, 2011), over each year of the historical series.

A simple extrapolation method was used from the given perspective; it is based on the development of a regression model that was determined by the time series of a single equation: the linear tendency equation. In addition, as stated by MISSIO \& JACOB (2007), models with independent dummy variables may be used in time series to check for changes in the intercepts and/or the slope of a function, which permits the identification of structural changes. Hence, the effect of the international wool crisis was simultaneously tested on models that represented both additive and multiplicative forms of the linear tendency equation. Starting from this point, it began the search for both tendency behavior in the productive variables and the presence (or absence) of a structural change, and the production patterns (of wool and meat) in Rio Grande do Sul and Uruguay were compared. This comparison resulted in the adjustment of the multiple regression model (equation 1) using the ordinary least squares method:

$Y_{i}=\beta_{0}+\beta_{1}$ Time $+\beta_{2}$ Change $+\beta_{3}$ Time.Change $+\varepsilon_{i}$

Where: $\mathrm{Y}_{1}$ is the productive variable for sheep production; $\mathrm{B}_{0}$ is the intercept parameter; $\mathrm{B}_{1}, \mathrm{~B}_{2}$ and $\mathrm{B}_{3}$ are the slope parameters; Time is the time of the historical series, which is represented by the numbers $0,1,2, \ldots$; Change is the dummy variable for the interceptive changes, and this term refers to the structural changes that occurred during the international wool crisis $(0=1974$ to $1990 ; 1=$ 1991 to 2009/2010); Time Change is the interaction variable (dummy and time for slope differences); $\boldsymbol{\varepsilon}_{\mathrm{i}}$ is the residue.

Estimations of intercept and slopes coefficients before and after the crisis allowed the creation of a base which evaluate the structural changes and the variables' tendencies with respect to sheep production in both regions. The formula for the analyses may be observed in equation 2 (before the crisis) and equation 3 (after the crisis), and these formulae first detail the dummy variable "Change," which is presented in equation 1 .

$$
\begin{aligned}
& Y_{\text {BeforeCrisí }}=\beta_{0}+\beta_{1} \text { Time }+\beta_{2} .0+\beta_{3} \text { Time. } 0= \\
& Y_{\text {BeforeCriss }}=\beta_{0}+\beta_{1} \text { Time }
\end{aligned}
$$

Ciência Rural, v.43, n.6, jun, 2013. 


$$
\begin{aligned}
& Y_{\text {AfterCrisis }}=\beta_{0}+\beta_{1} \text { Time }+\beta_{2} .1+\beta_{3} \text { Time } .1= \\
& Y_{\text {AfterCrisis }}=\left(\beta_{0}+\beta_{2}\right)+\left(\beta_{1}+\beta_{3}\right) \text { Time }
\end{aligned}
$$

In the period before the crisis, intercept comprehends $\mathrm{B}_{0}$ and the tendency of the productive variable refers to parameter $\beta_{1}$. In the period after the wool crisis, the intercept is $\left(\beta_{0}+\beta_{2}\right)$ and the tendencies (slopes) of the productive variables refer to $\left(\beta_{1}+\beta_{3}\right)$. There will be a structural change as long as there is a change in the variable's slope.

Thus, the analyses sought to verify if the wool crisis has caused a significant change in the trajectories of the variables related to sheep production, or whether the crisis marked the beginning of a new economical and productive scenario with respect to sheep activity. Both the existence or absence of a tendency of the variables to drop and rise and an identification of the structural changes in sheep production were verified using the t-student hypothesis test; the maximum significance level was $5 \%$.

Complementing the respective analyses of the variables' tendencies and the structural changes it was thus possible to evaluate the variations in sheep production in both regions of interest and before and after the wool crisis. It began with the estimation of a semi-logarithm (semi-log) that consisted of the same independent variables of equation 1 ; the semi$\log$ differed only in that it transformed the dependent variables (wool production, meat and sheep stock) into a natural logarithm. As the semi-log regression developed, the interpretation of coefficients was given using the annual rate of variation, according to equations 4 (before the crisis) and 5 (after the crisis).

$$
\begin{aligned}
& \% \Delta Y_{\text {BeforeCrisis }} \approx\left(100 . \beta_{1}\right) \Delta \text { time } \\
& \% \Delta Y_{\text {AfteCrisis }} \approx 100\left(\beta_{1}+\beta_{3}\right) \Delta \text { time }
\end{aligned}
$$

All of the results of the estimates were interpreted, related and discussed alongside the available literature, and these results compared the behavior of the productive variables in the sheep industries of Rio Grande do Sul and Uruguay and verified the change that occurred in the sector.

\section{RESULTS AND DISCUSSION}

In both Rio Grande do Sul and Uruguay, the evolution of the sheep stock from 1974 to 2009/2010 as a variable is visualized in figure 1, which allows a comparison between the periods before and after the wool crisis. An analysis of the variable "sheep stock" in table 1 shows a structural change beginning in 1991. Before the crisis, stock variation was caused exclusively by the ordinary production cycles.

With the advent of the wool crisis at the beginning of 1990, sheep production began to be entirely overhauled as a result of many producers' withdrawals from the industry. These producers withdrew due to the drop in wool prices and the substitution of sheep production with agricultural and for-profit cattle management (DIEA/MGAP, 2008). Table 1 shows the regression coefficients of the trend and structural changes $(\mathrm{Yt})$ for the sheep stock variables and the expected coefficients from the semi-logarithm estimation (which are expressed in variation rates) for Rio Grande do Sul (1974-2009) and Uruguay (1974-2010).

In Rio Grande do Sul, the sheep stock during the wool crisis period of 1974 to 1990 neither increased nor decreased, nor were there any significant coefficients; these characteristics have rendered it unstable. However, in Uruguay during the same period, the sheep stock had an increase of 3\% a year, according to the semi-logarithmic estimation; this statistic is based on an average of 668.590 units of sheep per year, and this figure was tested using the parameter $\beta_{1}$, which is significant at the level of $1 \%$.

When the coefficients for the period after 1991 are evaluated, an important structural change for the sheep stock variables in both regions is noticeable, due to the significance of the dummy intercept coefficient "Change" $\left(\beta_{2}\right)$ and the interaction coefficient "Time Change" $\left(\beta_{3}\right)$. Indeed, after 1991, there was a significant shift in the behavior of sheep farmers in both regions, and this shift was identified by modifying the angle that had a linear tendency for the variable that corresponds to the stock. From 1991 to 2009, Rio Grande do Sul sheep stock decreased at a rate of $5.9 \%$ a year, when it averaged 348,810 heads of annual decrease. Similarly, Uruguay was affected by the crisis wherein the total number of sheep decreased at the rate of $6.1 \%$ a year (1991-2010); thus, Uruguay averaged a loss of 950,650 heads per year. The coefficients of intercept and slope were significant (at a $1 \%$ rate of significance).

The evolution of wool production during this particular period can be associated with the sheep stock behavior. In Rio Grande do Sul, the number of sheep's remained stable until the early 1990's, which indicates that there was no change in the wool production. In Uruguay, the total stock increase in size led to an increase of wool production from 1974 to 1990. This phenomenon is commonly associated with 

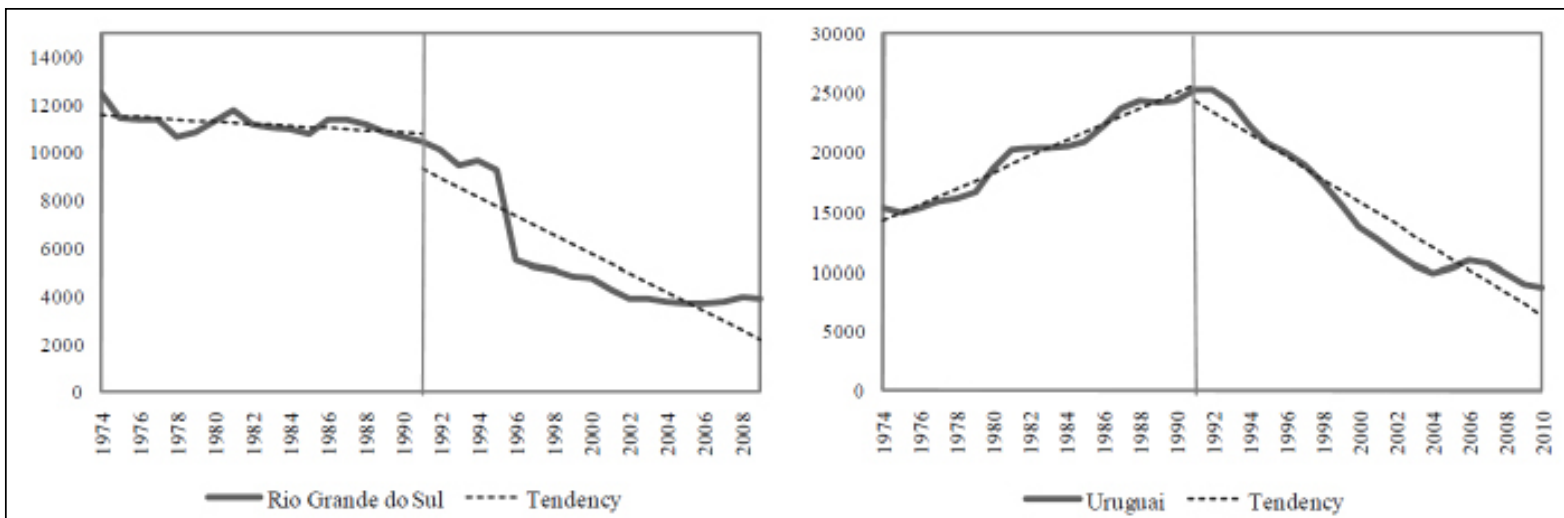

Figure 1 - The evolution of the sheep stock in Rio Grande do Sul and Uruguay; the international wool crisis is used as a point of reference (1991).

scale gains over productivity gains. Table 1 displays the estimated coefficients for the tendency and structural change $\left(\mathrm{Y}_{\mathrm{t}}\right)$ of the wool production variable, which are expressed in tons; furthermore, table 1 displays the estimated coefficients for the semi-logarithmic regression $\left(\ln \mathrm{Y}_{\mathrm{t}}\right)$, which is expressed in terms of the rate of variation. Wool production in Rio Grande do Sul from 1974 to 1990 did not show a tendency to increase or decrease, and thus, it was largely stable during this period. Uruguay presented an average growth of 2,263 tons annually, which represents a positive growth rate of $3.1 \%$ per year, as indicated by the semi-logarithmic estimates (the coefficients are significant at a rate of $1 \%$ of significance). However, when the relative coefficients for the period after the crisis were analyzed, a structural change for the wool production variable in both regions could be observed, because of the significance of $\mathrm{P}<0.01$ for both the dummy intercept coefficient "Change" $\left(\beta_{2}\right)$ and the interaction coefficient "Time Change" $\left(\beta_{3}\right)$.

Thus, a slope of axis is noticeable in the tendencies of wool production in Rio Grande do Sul and Uruguay. This slope decreased from 1991 to 2009/2010. Rio Grande do Sul's wool production has had a $5.6 \%$ decrease each year, with a declining average of 843.49 tons of fibers per year. After an

Table 1 - The linear $(\mathrm{Yt})$ and semi-log $(\operatorname{lnYt})$ regression coefficients that explain the tendencies and structural changes in the sheep production variables in Rio Grande do Sul and Uruguay from 1974 to 2009/2010.

\begin{tabular}{|c|c|c|c|c|}
\hline \multirow{2}{*}{ Models/ Coefficients } & \multirow[b]{2}{*}{$\mathrm{Y}_{\mathrm{t}}$} & \multirow[b]{2}{*}{$\ln \mathrm{Y}_{\mathrm{t}}$} & \multirow[b]{2}{*}{$Y_{t}$} & \multirow[b]{2}{*}{$\ln \mathrm{Y}_{\mathrm{t}}$} \\
\hline & & & & \\
\hline \multicolumn{5}{|l|}{ Sheep stock } \\
\hline Intercept $\left(\beta_{0}\right)$ & $11,593.88^{*}$ & $9.357^{*}$ & $14,305.50^{*}$ & $9.595^{*}$ \\
\hline Time $\left(\beta_{1}\right)$ & -45.92 & -0.004 & $668.59^{*}$ & $0.035^{*}$ \\
\hline Change $\left(\beta_{2}\right)^{* *}$ & $4,459.97^{*}$ & $0.863^{*}$ & $26,268.27^{*}$ & $1.612^{*}$ \\
\hline Time.Change $\left(\beta_{3}\right)$ & $-348.81^{*}$ & $-0.059^{*}$ & $-1,619.24^{*}$ & $-0.096^{*}$ \\
\hline \multicolumn{5}{|l|}{ Wool production } \\
\hline Intercept $\left(\beta_{0}\right)$ & $31,193.82^{*}$ & $10.347^{*}$ & $56,978.21^{*}$ & $10.97^{*}$ \\
\hline Time $\left(\beta_{1}\right)$ & -172.73 & -0.006 & $2263.021^{*}$ & $0.031^{*}$ \\
\hline Change $\left(\beta_{2}\right)^{* *}$ & $10,369.03^{*}$ & $0.798^{*}$ & $89,246.78^{*}$ & $1.452^{*}$ \\
\hline Time Change $\left(\beta_{3}\right)$ & $-843.49^{*}$ & $-0.056^{*}$ & $-5,574.62^{*}$ & $-0.087^{*}$ \\
\hline \multicolumn{5}{|l|}{ Sheep meat production } \\
\hline Intercept $\left(\beta_{0}\right)$ & $17,297.54^{*}$ & $9.823^{*}$ & $112,073.71^{*}$ & $11.643^{*}$ \\
\hline Time $\left(\beta_{1}\right)$ & $1,284.97^{*}$ & $0.043^{*}$ & $3,647.76^{*}$ & $0.025^{*}$ \\
\hline Change $\left(\beta_{2}\right)^{* *}$ & $50,046.99^{*}$ & $1.745^{*}$ & $30,986.56$ & 0.211 \\
\hline Time Change $\left(\beta_{3}\right)$ & $-2,846.38^{*}$ & $-0.099^{*}$ & $-4,800.63^{*}$ & $-0.034^{*}$ \\
\hline
\end{tabular}

$*(\mathrm{P}<0,01)$

** This binary variable exists due to the effects of the international wool crisis $(0=1974$ to $1990 ; 1=1991$ to $2009 / 2010)$.

Ciência Rural, v.43, n.6, jun, 2013. 
increasing period of wool production, Uruguay was affected by the International crisis of Rio Grande do Sul, which caused a decreasing rate of $5.6 \%$ of the annual wool production from 1991 to 2010 . This rate reflects an annual decrease of 3,311.61 tons of wool in Uruguayan production $(\mathrm{P}<0.01)$. In both regions, the estimated results for the variables corresponding to the sheep stock and the wool can be associated with the effects of the historical crisis, which have been mentioned.

Because of these difficult economic conditions, by the late 1980s and early 1990s, wool had lost much of its clientele and the worldwide wool industry crisis had begun, which was the main negative event for the industry. Furthermore, this event led to severe structural change, which is confirmed by the estimated regression models and the disorder in the sheep production activity. The impacts of the crisis were felt in the following years, which made the years after 1990 the worst period in the history of the wool industry, according to NOCCHI (2001); this period is known as "the harmful decade". The first impact of the crisis was an abrupt crash in the fiber prices in Rio Grande do Sul.

Uruguay's wool sector fell into crisis around 1990, when there was a 50\% reduction in the national sheep stock. Most of the changes in Uruguay, such as the period after the international wool crisis, can be categorized as follows: i) the replacement of the areas that had exclusively been used for sheep production to accommodate beef cattle; ii) a rise in rice production $(148 \%)$; iii) growth in the areas used for milk-producing cattle (59\%); iv) a notable rise in forested areas over livestock areas (920\%); v) a moderate increase in citrus and a decrease in horticulture (DIEA/MGAP, 2008; BIANCHI \& GARIBOTTO, 2008).
All of the cyclical negative events led to a consistent drop in wool prices worldwide. Whereas cotton and synthetic fibers dominated the textile industries, wool has mainly been used in high-quality garments, which are destined for more elite consumers (BOFILL, 1996). According to NOCCHI (2001), during the decade beginning in 1990, for all of the fiber consumption in the world only $1.4 \%$ were made from sheep wool. Parallel to the crisis in wool, sheep meat was considered to be alternative in the market.

However, the effects of the wool crisis on the total size of the sheep stock and on wool production in Rio Grande do Sul and Uruguay also reflect the behavior of sheep meat producers. Typical sheep meat production can be observed in figure 2, which permits a comparison between how the pertinent variable evolved before the crisis and how it evolved after the crisis. This variable evolved as follows: there was an evident drop until 2002, but production subsequently stabilized. The variable's estimates suggest that there were no generally established systems for sheep meat production in the two regions under study, and this result agrees with the results of CARDELLINO (2008).

In Uruguay, lamb and mouton production became cyclical, and there was a smaller drop in production, which is reflected in the variables that correspond to sheep stock and wool production in the same period. Nevertheless, periods of gains and losses of production are observed, and each of the periods lasts for two or three years; these changing periods are most likely caused by variations of the price paid for lamb meat.

Table 1 presents the estimated coefficients for the tendency, the structural change $\left(\mathrm{Y}_{\mathrm{t}}\right)$, and the estimated coefficient for the semi-logarithmic regression $\left(\operatorname{In} \mathrm{Y}_{\mathrm{y}}\right)$ for the variable corresponding to sheep meat production, which is expressed in tons.
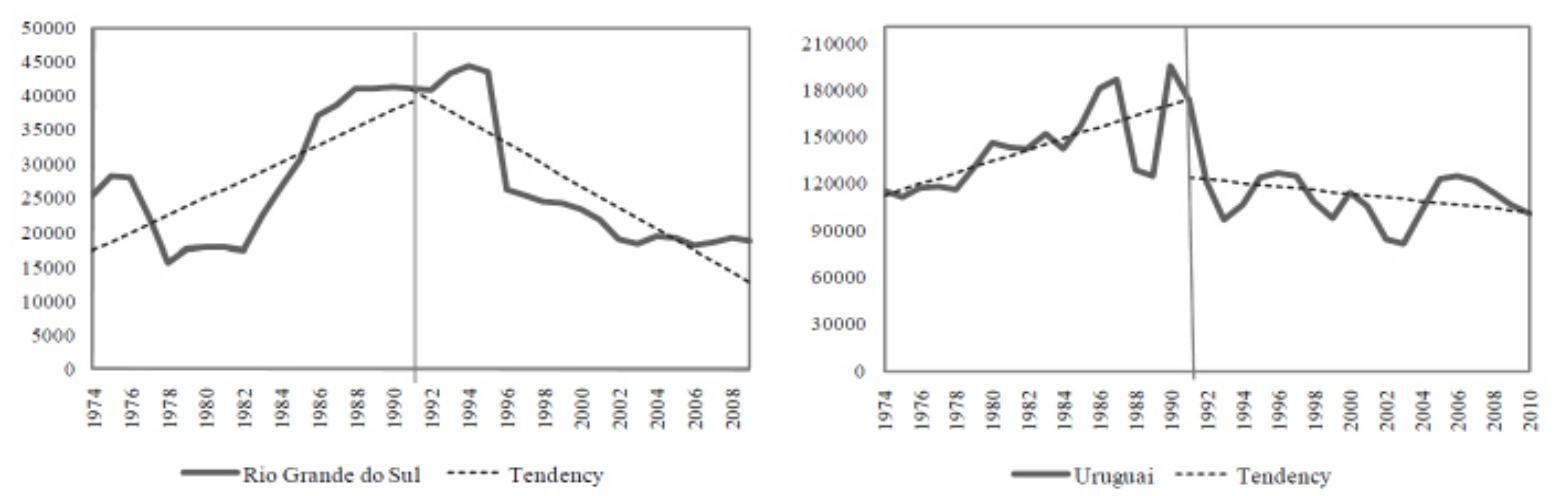

Figure 2 - The evolution of the sheep meat production (in tons) in Rio Grande do Sul and Uruguay; the international wool crisis is used as a point of reference (1991). 
The period from 1974 to 1990 saw a rise in the production of lamb in Rio Grande do Sul. Indeed, there was an average positive growth rate of $4.3 \%$ per year and an average annual production rise of 1,284.9 tons; these patterns are separate from the sheep stock and wool production variables. Similarly, Uruguayan production grew, and it averaged 3,647.7 tons of sheep meat per year and an annual positive growth rate of $2.5 \%$ (the coefficients $\beta_{1}$ of the linear and semi logarithmic regressions are significant at a $1 \%$ level of significance). It was determined that sheep stock and wool production had structural changes that were caused by the wool crisis. However, in Uruguay, the change was mostly observed at the slope of the variable's tendency $(\mathrm{P}<0.01)$, and the intercept change was not as significant.

In Rio Grande do Sul, sheep meat production decreased from 1991 to 2009, when it averaged 1,561.41 tons annually and had a negative growth rate of $5.6 \%$. However, it is noted that this result occurred mainly due to behavior of meat production in the 1990's; a much more regular pattern was observed after the year 2000. There was a similar decrease (in intensity) for all three variables in the sheep industry in Rio Grande do Sul, and these decreases are $5.6 \%$ for both sheep meat and wool and $5.9 \%$ for sheep stock. In addition, Uruguayan meat production decreased during the same period, although the decrease was not as dramatic in the post-crisis period of 1991-2010, when Uruguayan averaged an annual loss of 1,152.8 tons; this loss represents a negative growth rate of $0.9 \%$.

When sheep meat appeared to be a profitable production possibility, sheep farms in Rio Grande do Sul changed their production processes: ovine breeds specifically bred for their meat entered the market, the birth rate of the females was stimulated and production was focused on lambs for slaughter. Additionally, this opportunity was observed in Uruguay, becoming an important activity for familiar cattle breeders. However, it is important to note that Uruguayan sheep meat production has been cyclical ever since the crisis and there has been a slight overall decrease relative to the production of Rio Grande do Sul. After 2000, this behavior can primarily be associated with public and particular initiatives to promote lamb production (INIA, 2003) for slaughter; this production is intended for the international market, which enhances the slaughter rate, and consequently, the industry's productivity in Uruguay. These types of projects were not disseminated in a general way in Rio Grande do Sul, which precluded a significant growth in production; as a result, the historical behavior with respect to both lamb and sheep production was maintained there.

At the end of 2000, sheep production was susceptible to pressure from competitive agricultural markets with attractive profitability, such as grains, forestry and dairy cattle, and there has been historical competition with areas used for beef cattle (CARDELLINO, 2008). Within Rio Grande do Sul, meat became the main product in the sheep industry, which was boosted by the growth in sheep numbers in the Brazilian Northeast. Thus, even with the structural changes that occurred throughout the international wool crisis in those production variables that are related to sheep production, commerce with respect to sheep meat has emerged in the past few years as an alternative to the (re)frame of the sheep industry in Rio Grande do Sul and Uruguay.

\section{CONCLUSIONS}

Estimations using linear regression and semi-logarithm models have proven that structural changes occurred in sheep production in Rio Grande do Sul and Uruguay for the variables of sheep stock, wool production and sheep meat production. It was used the international wool prices in 1990/1991 as points of reference. The data from the models have indicated that there has been no return to a balanced situation after the changes related to the crisis. Thus, the sheep industry, which is based on the markets for wool and lamb, has been permanently affected by the wool crisis. Originally, these structural changes were made to maximize economical behavior, but they were made with limited foresight with respect to the long-term consequences of these changes. Consequently, a sheep farming restructuring occurred in which the production shifted from wool to meat.

\section{REFERENCES}

BIANCHI, G.; GARIBOTTO, G. ¿Lana o Carne? La oveja “embretada". EI Pais Agropecuario, ano 13, n.155. p. 30-35, 2008.

BOFILL, F. J. A reestruturação da ovinocultura gaúcha. Guaíba: Agropecuária, 1996. 137p.

CARDELliNO, R. El doble propósito en ovinos con lana fina: Una posibilidad cierta para Uruguay. EI País Agropecuario, v.14, n. 157, p. 32-34, 2008.

DIEA. Series históricas de datos: Ministerio de Ganadería, Agricultura y Pesca, 2011. Available from: $<$ http://www.mgap.gub. uy>. Accessed: Abr 02, 2011.

DIEA/MGAP. Regiones Agropecuarias 1990 y 2000: Uruguay Agroalimentario en Cifras. Montevideo: MGAP, 2008. 7p.

Ciência Rural, v.43, n.6, jun, 2013. 
FAO. Estatísticas - FAOSTAT, 2011. Available from: <http:/ faostat.fao.org > . Accessed: jan 05, 2011.

IBGE. Banco de dados agregados - SIDRA. Temas: Pecuária. Available from: $<$ http://www.sidra.ibge.gov.br>. Accessed: abr 02, 2011.

INIA. Producción de carne vacuna y ovina de calidad Treinta y Tres: Instituto Nacional de Investigación Agropecuaria, Actividades de difusión 317, 2003. 158p.
MISSIO, F.; JACOBI, L. F. Variáveis dummy: especificações de modelos com parâmetros variáveis. Ciência e Natura, v.29, n.1, p.111-135, 2007.

NOCCHI, E.D. Os efeitos da crise da lã no mercado internacional e os impactos socioeconômicos no município de Santana do Livramento - RS- Brasil. 2001. 71f. Dissertation. (Master in International Cooperation and Integration) - National University of Rosario, Argentina. 